\begin{tabular}{|c|c|c|}
\hline institute & $\begin{array}{l}\text { CARADDE: Jurnal Pengabdian Kepada Masyarakat } \\
\text { https://journal.ilininstitute.com/index.php/caradde } \\
\text { Volume 1 | Nomor 1 | Agustus | } 2018 \\
\text { e-ISSN: } 2621-7910 \text { dan p-ISSN: } 2621-7961 \\
\text { DOI: https://doi.org/10.31960/caradde.v1i1.14 }\end{array}$ & $\begin{array}{l}\text { IUiN } \\
\text { CARADDE }\end{array}$ \\
\hline
\end{tabular}

\title{
Program Sosialisasi Akuntansi Keuangan Berdasarkan SAK Berbasis IFRS di SMK Veteran Kota Cirebon
}

\author{
${ }^{1)}$ Ida Rosnidah, ${ }^{2)}$ Juwenah, ${ }^{3)}$ Apri dwi astuti, ${ }^{4)}$ Kayati
}

Keywords :

IFRS;

motivasi;

SAK;

sosialisasi.

\section{Corespondensi Author}

1) Audit, Fakultas Ekonomi, Universitas Swadaya Gunung Jati J1 Pemuda no 32, Kota Cirebon, Jawa Barat

Email:apri_dwiastuti@yahoo.co.id

\section{History Artikel}

Received: Juni-2018;

Reviewed: Juli-2018

Accepted: Juli-2018

Published: Agustus-2108
Abstrak. Tujuan kegiatan Program Sosialisasi Akuntansi Keuangan Berdasarkan SAK Berbasis IFRS di SMK Veteran Kota Cirebon untuk meningkatkan kemampuan dan kualitas Sumber Daya Manusia khususnya para siswa SMK Veteran di Kota Cirebon dalam bidang ilmu akuntansi keuangan berdasarkan $S A K$ berbasis IFRS, sehingga dapat dijadikan bibit-bibit unggul yang potensial untuk diasah menjadi Akuntan Profesional masa depan. Metode pelaksanaan yang dilakukan dalam kegiatan ini adalah :(1) memberikan sosialisasi terkait materi terbaru mengenai perkembangan akuntansi terutama tentang SAK Berbasis IFRS, (2) sosialisasi mengenai motivasi belajar akuntansi berdasarkan $S A K$ Berbasis IFRS dan motivasi kerja dalam bidang akuntansi. Hasil dari kegiatan adalah meningkatnya pengetahuan tentang SAK serta IFRS. Hal ini dilihat dari hasil pre test yang disebar oleh tim pelaksana danmeningkatnya motivasi para siswauntuk memilih bekerja didunia akuntan dan menjadi akuntan yang profesional dengan mengambil jurusan akuntansi jika melanjutkan ke jenjang pendidikan yang lebih tinggi..Kesimpulan pada kegiatan pengabdian ini antara lain adanya peningkatan pengetahuan para siswa tentang informasi terbaru pada dunia akuntansi dimana sekarang sudah berbasis IFRS. Hal ini dibuktikan dengan hasil pre test.Meningkatnya motivasi untuk bekerja menjadi akuntan yang profesional..

\section{PENDAHULUAN}

Masalah utama dalam kehidupan manusia adalah sumber daya ekonomi sangat langka sedangkan kebutuhan manusia bersifat tidak terbatas. Agar dapat bertahan hidup dan meningkatkan taraf hidup yang lebih baik, manusia harus pandai mengelola dan memanfaatkan sumber daya ekonomi yang terbatas secara efisien dan efektif. Akuntansi adalah salah satu metode perhitungan dan pelaporan sumber daya ekonomi yang berkembang seiring dengan perkembangan peradaban manusia (Mankiw, 2016).

Abad ke-21 dimana kebutuhan manusia semakin meningkat baik kuantitas, kualitas maupun keragamannya, maka rumah tangga, perusahaan, organisasi, dan negara perlu pandai mengelola sumber daya ekonomi, dana, dan keuangan supaya tidak terjadi "lebih besar pasak daripada tiang" lebih besar beban daripada pendapatan (Warren, 2017). Oleh karena itu, kita perlu memahami sistem 
dan metode perhitungan dan pelaporan keuangan dengan baik, maka akuntansi adalah prasarana pokok untuk menuju kemakmuran dan kesejahteraan (Belkaoui, 2016).

Akuntansi keuangan dapat dikatakan merupakan tulang punggung atau proses dasar sistem informasi akuntansi dalam suatu entitas unit usaha, dan juga merupakan jalur informasi penting antar unit mikro (entitas bisnis) dengan unit makro (publik, entitas pemerintah, dan negara). Akuntansi keuangan bertujuan menyusun laporan keuangan yang andal dan tidak memihak untuk digunakan oleh para pemangku kepentingan entitas pelaporan (kartikahadi, 2016).

Dalam era globalisasi dan seiring dengan dinamika bisnis, produk akuntansi keuangan menjadi makin kompleks dan harus dapat dibaca dan digunakan oleh para pemangku kepentingan (stakeholders) yang tersebar secara global. Ikatan Akuntan Indonesia (IAI) melalui organnya, Dewan Standar Akuntansi Keuangan (DSAK) telah secara tanggap mengikuti gelombang konvergeni standar akuntansi keuangan nasional ke standar akuntansi internasional, yaitu dengan menyusun Standar Akuntansi Keuangan (SAK) berbasis International Financial Reporting Standards (IFRS) (IAI, 2015).

Kendala yang sedang dihadapi dunia pendidikan akuntansi di indonesia adalah masih langkanya textbook akuntansi keuangan indonesia yang dapat diandalkan mengikuti perkembangan akuntansi yang sangat dinamis ini. Banyak perguruan tinggi di indonesia yang masih mengandalkan buku wajib Amerika Serikat yang berdasarkan standar akuntansi Amerika Serikat yang berbasis US GAAP (United States Generally Accepted Accounting Principles), padahal dalam praktik penyusunan laporan keuangan di Indonesia wajib berdasarkan SAK yang berbasis IFRS. Beberapa textbook Akuntansi Keuangan Berbasis IFRS yang tersedia di pasar tidak sepenuhnya dapat digunakan karena menggunakan versi IFRS yang berbeda dengan versi yang diadopsi SAK (Nunik, 2010).

Masalah akuntansi keuangan berkaitan erat dengan peraturan perundangan dan hukum positif yang berlaku di suatu negara. Agar lebih "membumi" dalam pembahasan diusahakan merujuk ke peraturan perundangan dan hukum yang berlaku di Indonesia yang sesuai dengan perkembangan SAK berbasis IFRS yang beralih dari rule-based ke principle-based (kartikahadi, 2016).

Program Akuntan Mengajar di SMK merupakan bagian dari upaya untuk meningkatkan pemahaman calon akuntan Indonesia, serta untuk menemukan bibitbibit unggul yang potensial untuk diasah menjadi Akuntan Profesional masa depan. Hal ini sejalan dengan upaya pemerintah untuk meningkatkan kompetensi SDM guna mengisi kebutuhan tenaga kerja terlatih dalam beberapa tahun ke depan. Sesuai proyeksi Kementerian Tenaga Kerja RI, hingga tahun 2030 dibutuhkan sekitar 3,8 juta tenaga kerja terlatih setiap tahun untuk menopang pertumbuhan sektor industri. Profesi akuntan merupakan bagian penting untuk memastikan perekonomian Indonesia masuk dalam jajaran 7 (tujuh) besar dunia pada tahun 2030 (www.psmk.kemdikbud.go.id).

Program ini merupakan bentuk nyata pengabdian masyarakat yang berupa pembinaan kepada masyarakat, khususnya para siswa SMK di kota Cirebon. Program ini, selain akan semakin mendekatkan Akuntan kepada stakeholders pendidikan di tingkatan SMK juga untuk meningkatkan sinergi para pemangku kepentingan di dunia akuntansi, memotivasi dan meningkatkan pemahaman generasi muda tentang akuntansi keuangan berdasarkan SAK berbasis IFRS, ilmu dan profesi akuntansi. Melalui program ini, diharapkan para akuntan untuk berbagi ilmu mengenai akuntansi keuangan berbasis IFRS dan pengalaman profesionalnya kepada siswa di SMK kota Cirebon.

Kerangka pemecahan masalah pada kegiatan ini adalah memberikan sosialisasi materi terkait akuntansi keuangan berdasarkan SAK berbasis IFRS di SMK Kota Cirebon, kegiatan tersebut merupakan bagian dari upaya untuk meningkatkan pemahaman calon akuntan Indonesia, serta untuk menemukan bibit-bibit unggul yang potensial untuk diasah menjadi Akuntan Profesional masa depan. Program ini juga merupakan kegiatan pengabdian yang sejalan dengan upaya pemerintah untuk meningkatkan kompetensi Sumber Daya 
Manusia (SDM) khususnya bidang akuntansi guna mengisi kebutuhan tenaga kerja terlatih dalam beberapa tahun ke depan.

Berdasarkan hal diatas, tujuan kegiatan ini meningkatkan pemahaman siswa dan siswi SMK Kota Cirebon mengenai Akuntansi Keuangan berdasarkan SAK Berbasis IFRS, serta untuk menemukan bibitbibit unggul yang potensial untuk diasah menjadi Akuntan Profesional masa depan.

\section{METODE}

Metode yang diterapkan untuk mencapai pemecahan permasalahan ini adalah metode sistem tindakan dan pembelajaran yang partisipatif yang dikenal sebagai metode PALS (Participatory Action and Learning System). Metode pemberdayaan masyarakat ini dikembangkan oleh Linda Mayoux tahun 2000-an (Chambers, 2007). Dengan metode PALS ini, proses dan evaluasi dilaksanakan secara partisipatif. Evaluasi program dilakukan terhadap proses, outcome, dan stakeholders' (Jones, 2014).

Aktivitas kegiatan ini memiliki tahapan pelaksanaanya sebagai berikut : (1) sosialisasi akuntansi keuangan berdasarkan SAK Berbasis IFRS. Program pengabdian ini dilaksanakan dengan memberikan Materi terkait akuntansi keuangan berdasarkan SAK berbasis IFRS. Pemberian materi diisi oleh Prof. Dr. Hj. Ida Rosnidah, SE., MM., Ak., CA, Narasumber dari setiap pelatihan yang terdiri dari akuntan pendidik dan mempunyai pengalaman praktek di bidang akuntansi. Pelatihan ini dihadiri oleh 155 siswa dan siswi kelas XII. Pelatihan ini bertempat di Aula SMK Veteran Kota Cirebon. (2) sosialisasi mengenai motivasi belajar akuntansi berdasarkan SAK Berbasis IFRS dan motivasi kerja dalam bidang akuntansi. Tim pelaksana pengabdian membagikan kuesioner terkait pilihan para siswa dengan minat kerja didunia akuntan.

\section{HASIL DAN PEMBAHASAN}

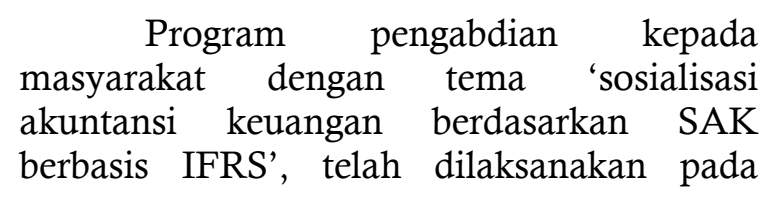

tanggal 9 Januari 2018, bertempat di Aula SMK Veteran Lantai 2. Peserta sosialisasi adalah siswa dan siswi SMK Veteran Kota Cirebon khususnya kelas XII dan dihadiri oleh 155 siswa-dan siswi SMK Kota Cirebon (www.smkveterancirebon.sch.id). Program pengabdian ini dilaksanakan dengan memberikan Materi terkait akuntansi keuangan berdasarkan SAK berbasis IFRS. Pemberian materi diisi oleh Prof. Dr. Hj. Ida Rosnidah, SE., MM., Ak., CA (Dosen Akuntansi Fakultas Ekonomi Universitas Swadaya Gunung Jati). Tenaga pengajar memiliki kemampuan di bidang Akuntansi Keuangan berdasarkan SAK Berbasis IFRS. Sosialisasi ini dibuka oleh Kepala Sekolah SMK Veteran dan dihadiri oleh Kepala Kurikulum beserta guru-guru SMK Veteran Kota Cirebon. Output dari sosialisasi materi ini berupa pemberian pre test kepada para siswa mengenai materi sosialisasi. Pre test ini tidak dinilai tapi dilihat secara keseluruhan bagaimana para siswa menyerap materi terkait dengan akuntansi keuangan berdasarkan SAK berbasis IFRS. Pre test ini berisi 10 pertanyaan yang berbentuk pilihan ganda. Hasil dari pre test adalah kebanyakan para siswa memahami materi tentang SAK berbasis IFRS.

Disamping sosialisasi terkait SAK Berbasis IFRS, diisi juga materi motivasi terkait dengan dunia kerja profesi akuntan. Hal ini mendorong agar para siswa lebih tertarik dengan akuntansi. Selain itu untuk melihat seberapa antusias para siswa dengan dunia akuntan dan alasan mengapa mereka memilih jurusan akuntansi. Output dari motivasi ini dilihat dengan cara membagikan kuesioner kepada para siswa. Hasil dari output ini kebanyakan memilih profesi akuntansi nantinya ketika memasuki dunia kerja. Para siswa juga menuliskan alasannya ketika mengambil profesi akuntan dengan mengambil jurusan akuntansi diperguruan tinggi untuk menambah pengetahuan jika mereka tidak langsung terjun ke dunia kerja.

Di bawah ini foto-foto kegiatan pelaksanaan Sosialisasi Akuntansi Keuangan Berdasarkan SAK Berbasis IFRS Di SMK Veteran Kota Cirebon. Foto dibawah menunjukkan persiapan penyampaian materi, penyampaian materi dan evaluasi materi. 

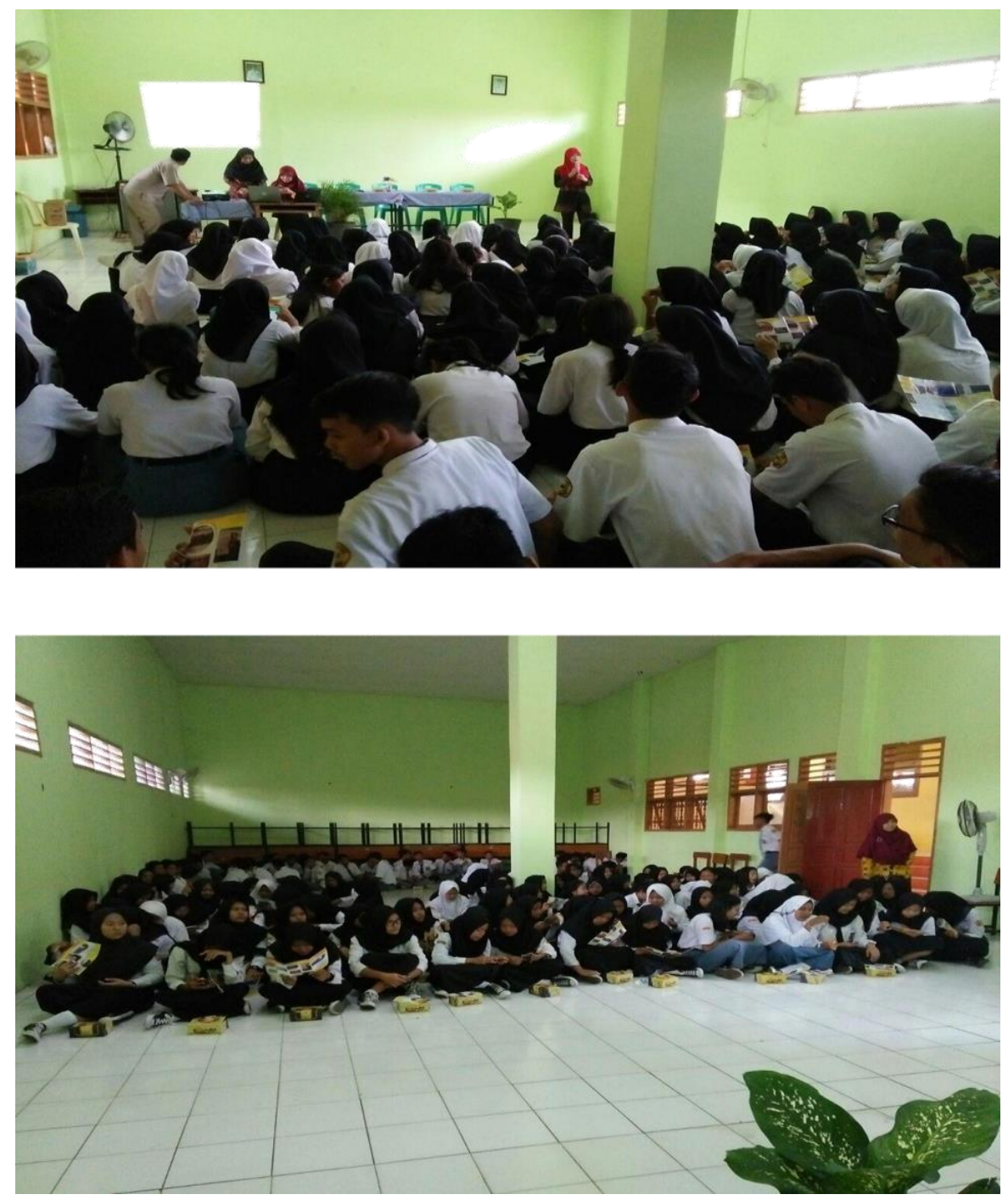

Gambar: Tim memberikan materi

\section{SIMPULAN DAN SARAN}

Kesimpulan pada kegiatan pengabdian ini antara lain adanya peningkatan pengetahuan para siswa tentang informasi terbaru pada dunia akuntansi dimana sekarang sudah berbasis IFRS. Hal ini dibuktikan dengan hasil pre test.Meningkatnya motivasi untuk bekerja menjadi akuntan yang profesional. Saran untukpengembangan ilmu akuntansi adalah agar SAK berdasarkan IFRS dimasukkan dalam kurikulum pelajaran akuntansi SMK.

\section{DAFTAR RUJUKAN}

A.Jones, S. (BLS, ACLS dan PALS). 2014. Jakarta: Erlangga.
Belkaoui, A. (2016). Teori Akuntansi. Jakarta: Salemba Empat.

Chambers, A. (2007). Accounthing Theory. Jakarta: Salemba Empat.

Citha, R. (2017, November kamis). Tenaga Kerja Berdasarkan Lulusan. Retrieved Desember 2, 2017, from https://psmk.kemdikbud.go.id: https://psmk.kemdikbud.go.id/konten /2755/data-tenaga-kerja-indonesiaberdasarkan-lulusan

Hans Kartikahadi, R. U. (2016). Akuntansi Keuangan Berdasarkan SAK Berbasis IFRS. Jakarta: IAI.

IAI, D. (2012). Standar Akuntansi Keuangan. Jakarta: IAI.

Mankiw, N. (2016). Pengantar Ekonomi. Jakarta: Gramedia. 
Nunik. (2010). Perbedaan IFRS, U.S.GAAP dan PSAK: Investement Property. Akuntansi, 59-69.

Veteran, T. S. (2014, Agustus Rabu). smk veteran kota cirebon kesiswaan. Retrieved Desember 2, 2017, from http://www.smkveterancirebon.sch.id: http://www.smkveterancirebon.sch.id/ html/siswa.php?id=dbsiswa

Warren, C. (2017). Pengantar Akuntansi. Jakarta: Salemba Empat. 